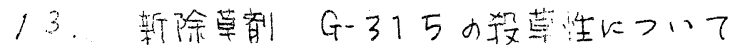

\section{河村雄司，宇野良則，新找房子。后田精一，小野騏一 (日座化学研究新)}

斯除草斉G-315(5-t-butyl-3-(2.4-dichloro-5-isopropoxyphenyl) 1.3.1-0xa-

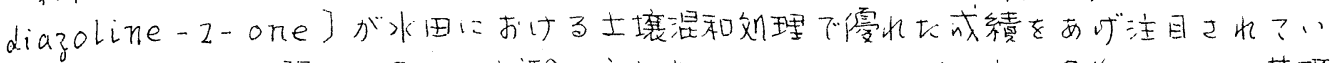

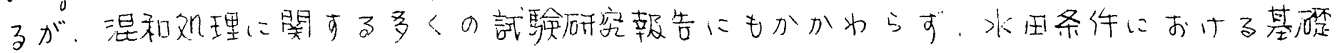
的敒知是ははとんど得られていない。

水田における湜和迈理の一般的份長新としては

1. 処理層の破かいに起因する効果の低下, 变動が小心い。

2. 成分の分解, 流亡が少ない。

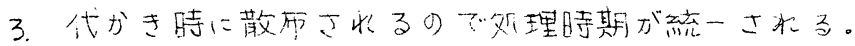

4. 散历沛方是正される

5.散布技㻭の省力似が可能に゙る。

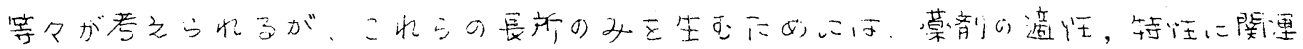

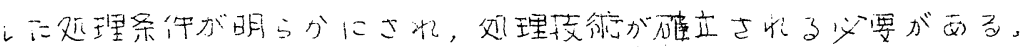

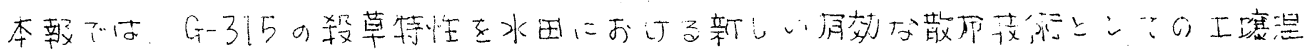

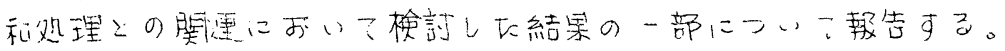

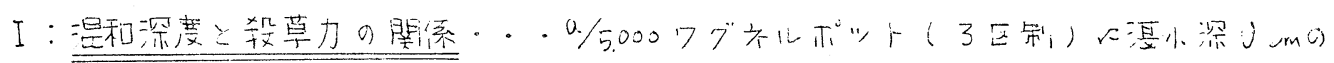

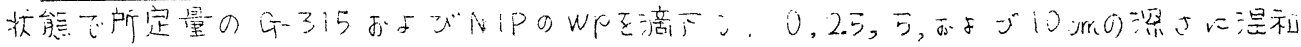

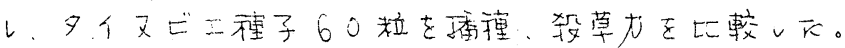

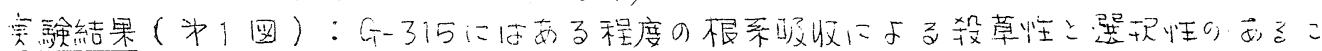

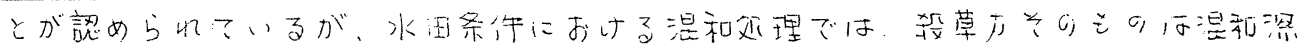

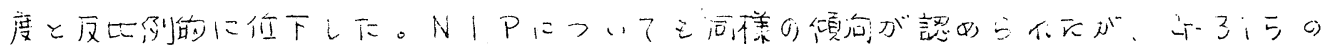

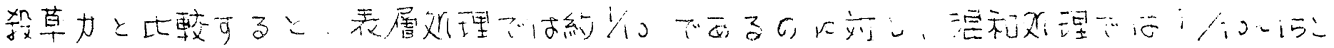

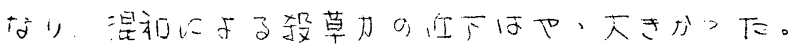

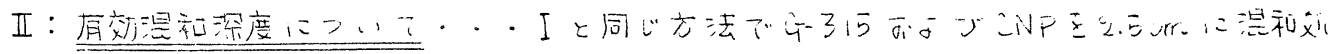

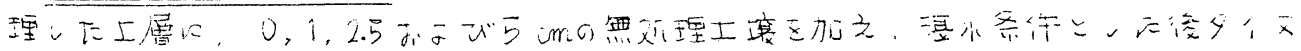
ビエを橎䄇し、轧草力区医較した。(

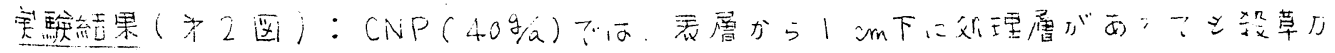

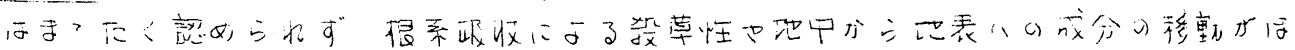

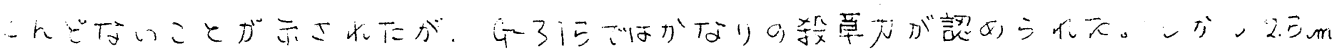

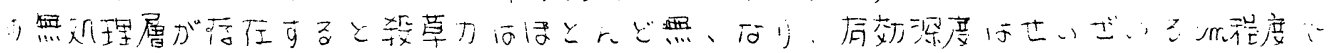
あることが判つた。

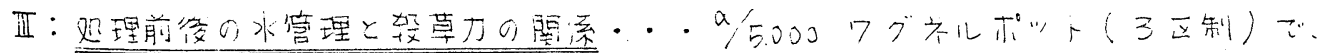

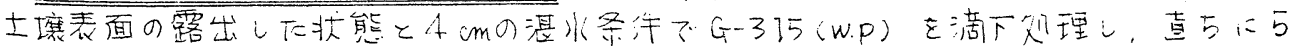

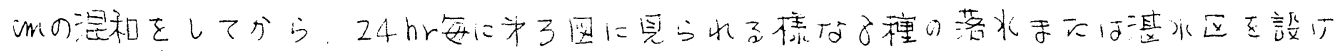

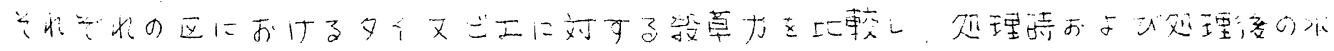

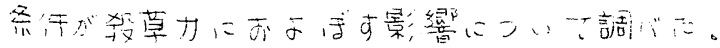



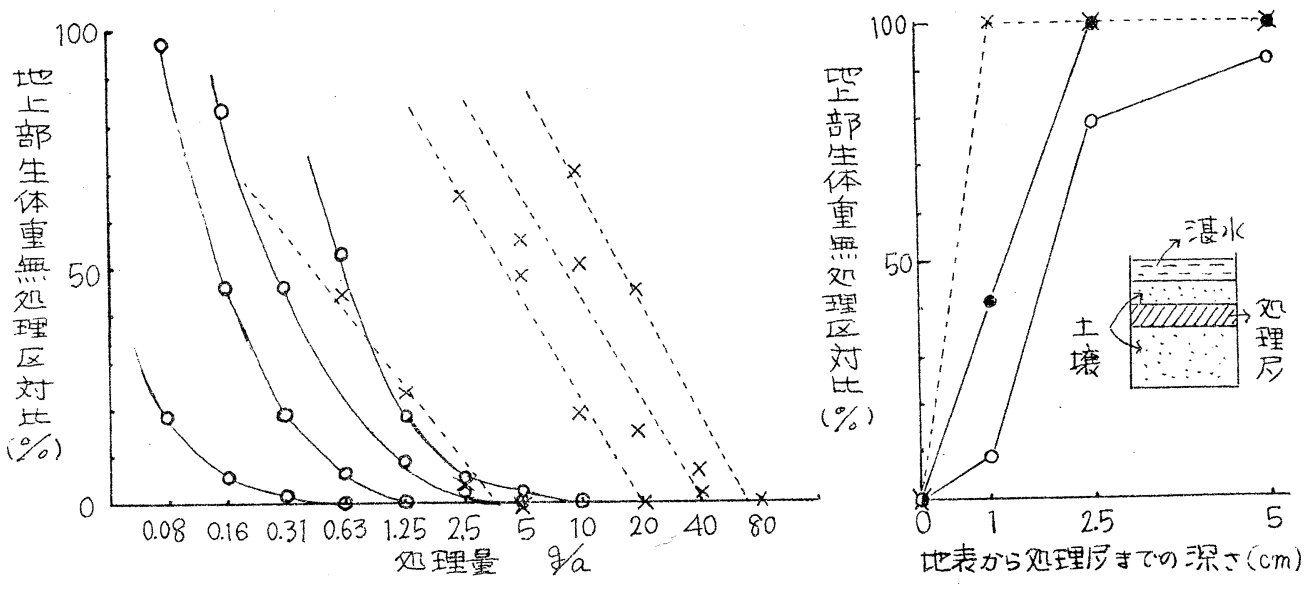

为1四湜和深度と殺草力の関係

为2四有効湿和深度

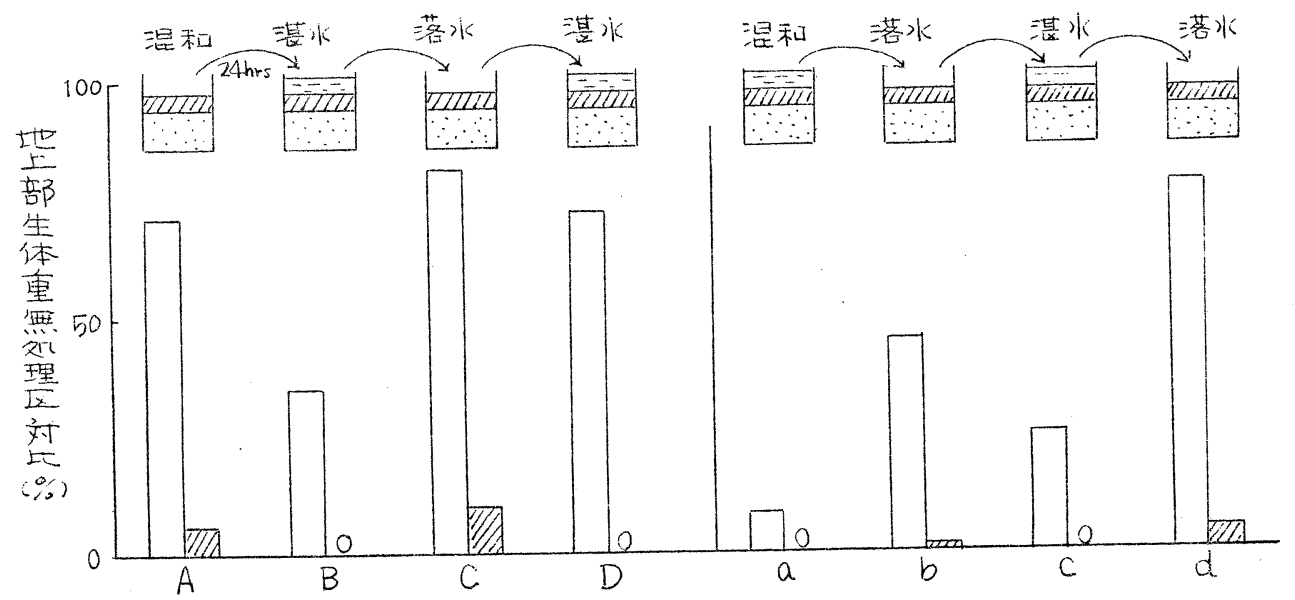

为了四处理前後の水管理と殺草力の関係

宝験結果( 为了四): 湛水条件下における湜和処理は、無湛》条件下における混和処 理より、处理後の水条件は同一であ?ても殺草力は也一大きく、同じ方法で星和し

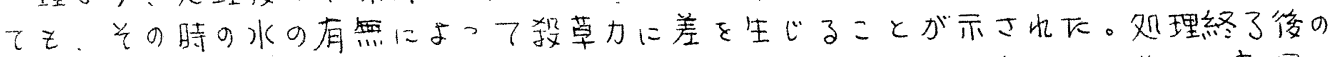

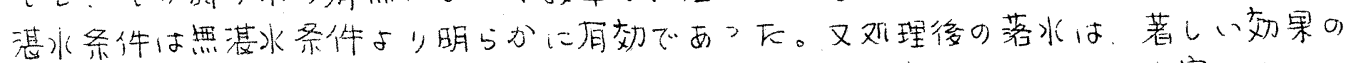
任下とはならず、Gー315 成分の田面水洫度が光んなに高くなっことを推察させ下。

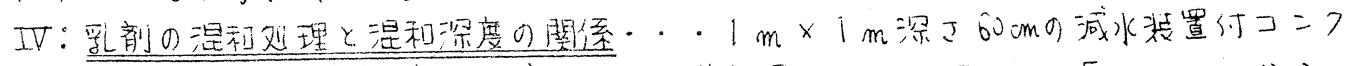

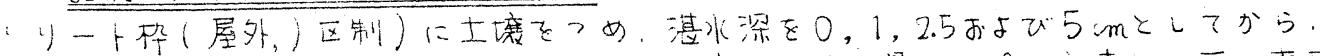

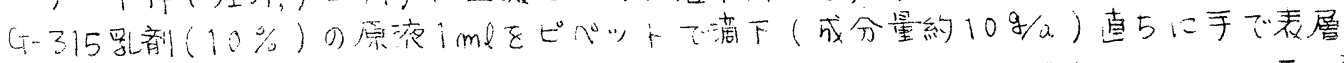

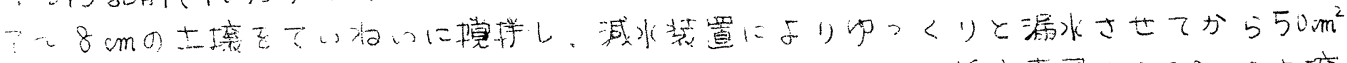

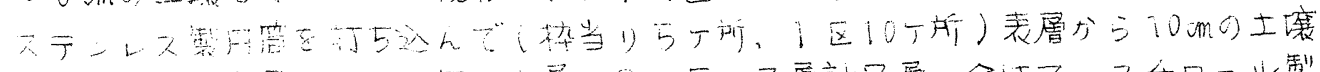

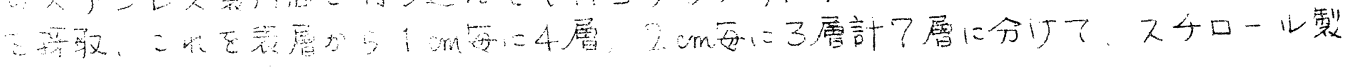
$(48)$ 


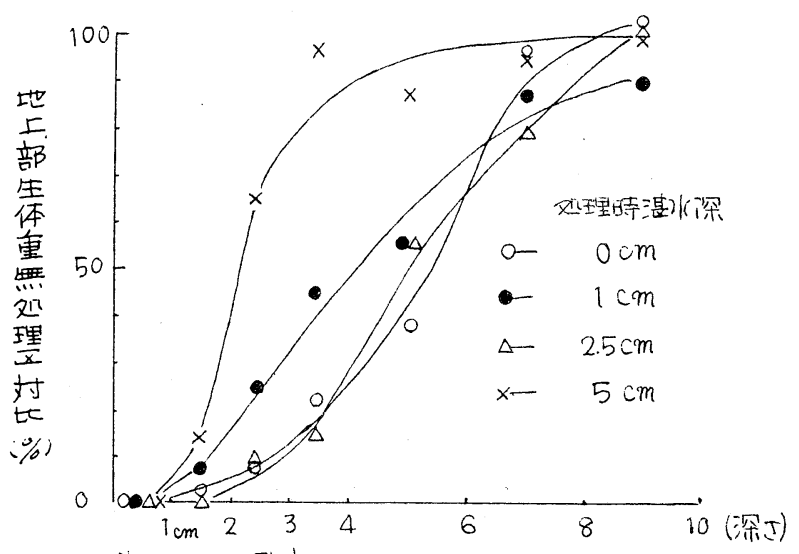

为4图乳闵の昆和处理と湜和深度
アイスフリーム平カップに入れ、

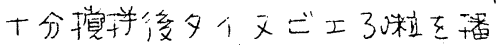

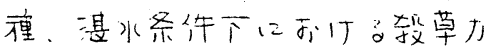

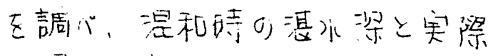
の混和深度の菲係を定性能に知 るンとした。

䒠駼結果( 邓4这)：湜和時の 湛小深の有無、深浅を間内ず 散艮されたG-315乳剂の成分が 表屡に近いまど多量に分布して 、る傾句のあることが示され饥 が $02.5 \mathrm{~cm}$ の湛水条件下に おける混和処理では。地表乃 ら数的下方の土壇中にも明 为1表処理後田面水中における除草剂の消長 らかにG-315 の存在が認め られた。しか レ $5 \mathrm{~cm}$ の沮 水条件下では 同一の方法で 芘和作業を行 な> $7 \notin 3 \mathrm{~cm}$ 以下の土壤に はほとんど殺 草刀は認めら れず、散师し たG-3159大 半が表層近く に存在しい わ的る浅心观 理層，浅山琵 和ができる可 能性のあるこ

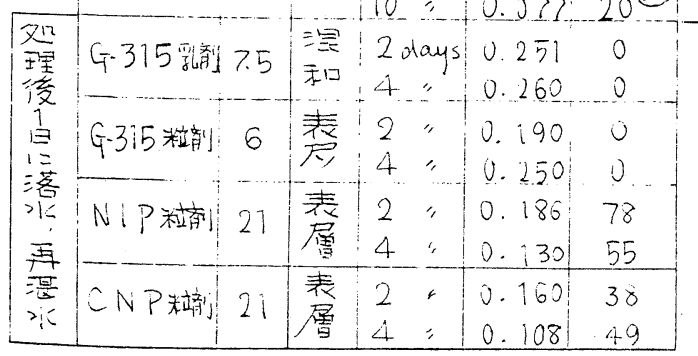

(49)
とが西された。

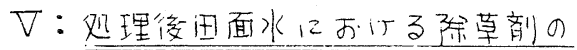

\section{消長}

a/5.000ワブネルボット(2区制)を 使用。 $1 \mathrm{~cm}$ 日湛水条件にG-315乳剂 おちび粒斉，CNPおすびN1P粒敖を 散㸞、Gー315乳刘のみは、表層力ら 


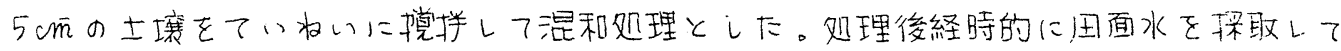
ヘキサンで成分を抽出、漕縮してガスフロマトグラフ法で分析した。一方同じ田面闪

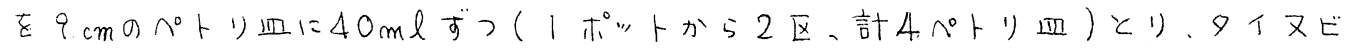

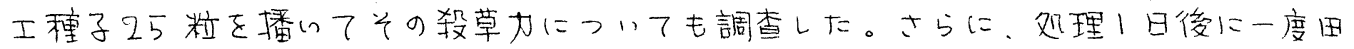
面水を落水(サイホン便用)してから再甚水したものについても分析とBioassayで 㭘討を加之た。又别の実験では、処理の代かきの有無，施肥の有無と眮係についてZ 調べた。 前

実験結果（为了表）：供試了刘の水溶解度は1 p p m 程度で差がないが、田面水におい

ては、大差が垫められた。G-315乳刘の混和观理が最終的には濃度が高かっ下が、 如理直後においてては。CNP䊉剂は水溶解度を越す成分の水中への分散が認められ下。

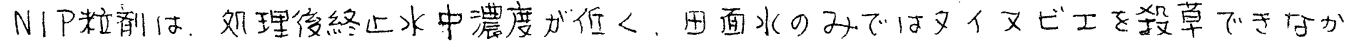

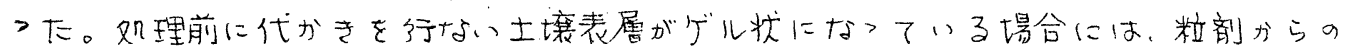
成分の溶出量(速度) は大巾に減少し下。しかし本試偷条件内では、Gー315乳刘は

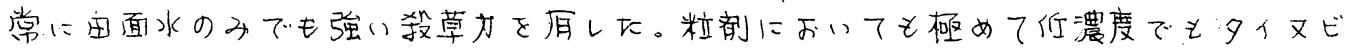
エはほとんど佰死した。

$\nabla I ： G-3150$ 処理法と効力の持続性の関係・・屋外に女るコンクリートポット(

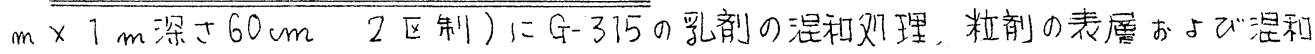
処理を行なって, 剂形, 处理法による効力の持続性の実用的な差を比較した。混和は

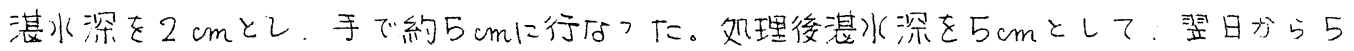
日間 $2 \mathrm{~cm} / 8 \mathrm{hrs} /$ day の減水を实施し、以後は自然条件下においた。( 6 月9日忛理)

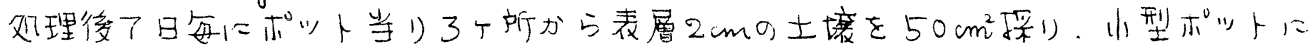
入れて、タイヌビエ種子３０䊉を橎き、湛水条件下にホ、る殺草力を調べた。

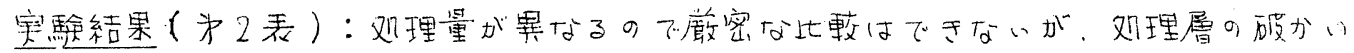
の攵い条件でも。混和观理 の残効性は表層㞶理より長い 傾向がありた。乳绪の混和忛 理は粒刘よりや、短かく、5 心程度の湜和深であれば。粒

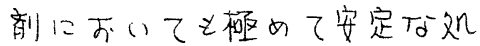
理層が形成されると考之られ る。乳剖の残効の中、短い根 权としては观理層の愿さと 田面水の成分灌度の差があげ

为2表G-3150処理法と効力の持続性

\begin{tabular}{|c|c|c|c|c|c|c|c|c|c|c|}
\hline \multirow{2}{*}{ 供試苩刘 } & \multirow{2}{*}{\multicolumn{2}{|c|}{$\begin{array}{c}\text { 婴理 } \\
\text { 法 } \\
9 / a\end{array}$}} & \multicolumn{8}{|c|}{ 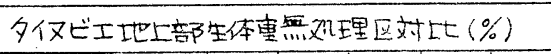 } \\
\hline & & & 7日後 & 14 & 21 & 28 & 35 & 42 & 49 & 56 \\
\hline \multirow{2}{*}{$\begin{array}{l}G-315 \\
\text { 粒绪 } \\
\end{array}$} & 表 & 6 & 0 & 0 & 0 & 0 & 20 & 54 & 84 & 103 \\
\hline & 混 & 10 & 0 & 0 & 0 & 0 & 0 & 0 & 3 & 2 \\
\hline \multirow{2}{*}{$\begin{array}{r}G-315 \\
\text { 乳剂 }\end{array}$} & \multirow{2}{*}{ 混 } & 7.5 & 0 & 0 & 0 & 0 & 6 & $a$ & 47 & 44 \\
\hline & & 10 & 0 & 0 & 0 & 0 & 1 & 0 & 10 & 18 \\
\hline 無処理 & - & - & 100 & 100 & 100 & 100 & 100 & 100 & 100 & 100 \\
\hline
\end{tabular}
ら《る。 


\section{4.新除草削Gー315のイネにおよばす影響}

河村雄司, 宇野良則, 新井房子, 后田䞍一, 小野騏一 (日座化学研究所)

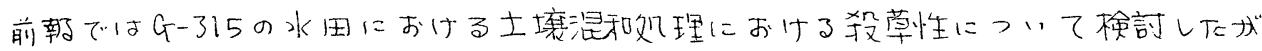
本報では。主として混和处理における水稻に奶可莧害についフ試験をした結果につい て報告する。

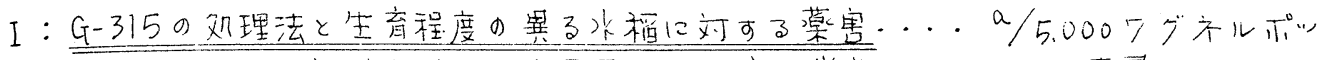

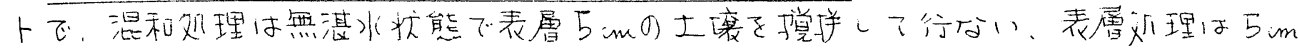

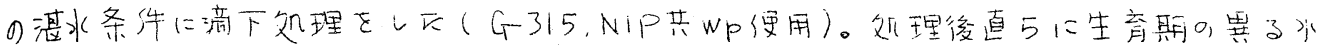

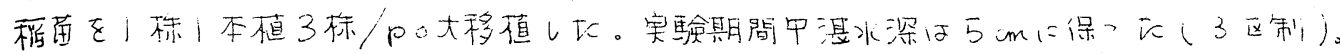

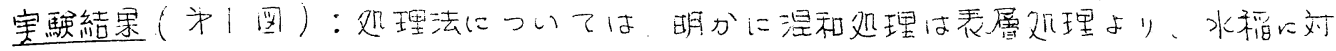

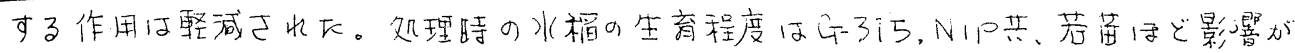

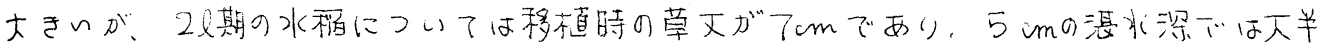

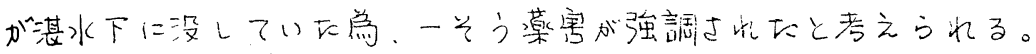

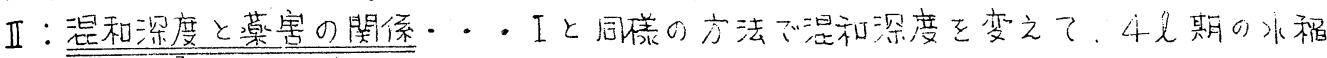

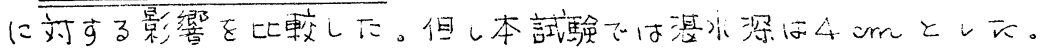

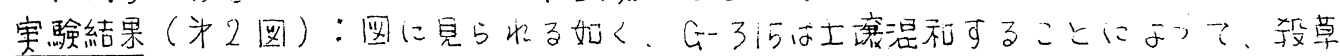

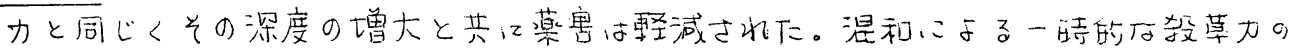

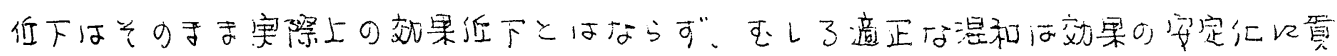

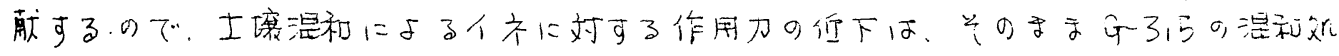
理の有利性を示可ものと考之られる。

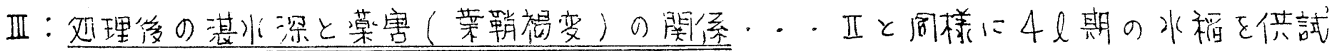

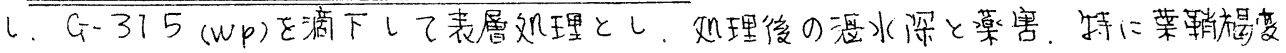

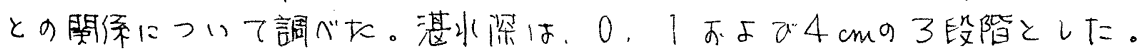

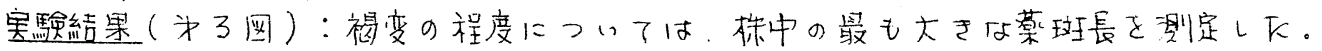

Gー315の場合に专、でにNIP CNPで知られているよるに。明らかに深水夺件に らいて裼变は大きいようである。しかし、褐变の大きさに其られるような差は实際の 水稻の生育样相には理中れず、特に菜令にはほと人ど影䓳しなかつた。

IV: G-3159个齐体风によ丁る消長と分布・・2 $200 \mathrm{ml} 三$ 角コルベニに0.1ppma

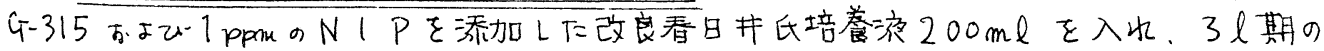

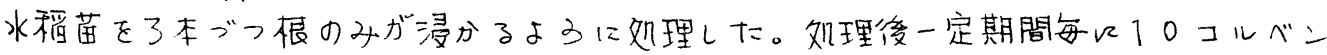

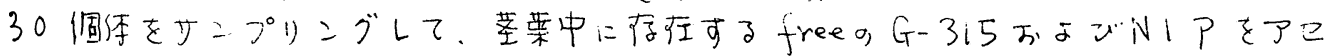

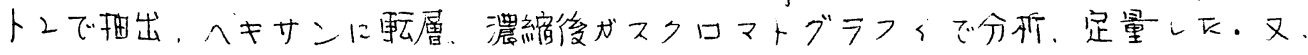

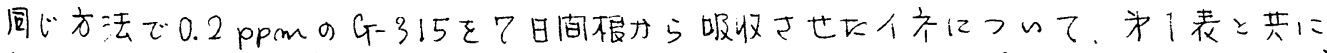

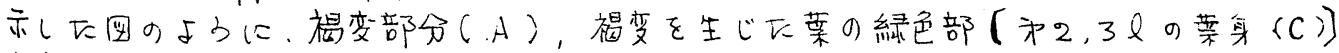

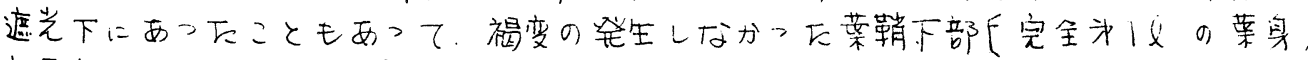
生長点部分を含む(B)了, 观理後展南し、サンプリンブ時にはほとんど不估水ていた

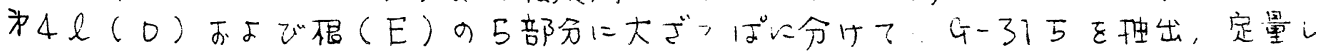



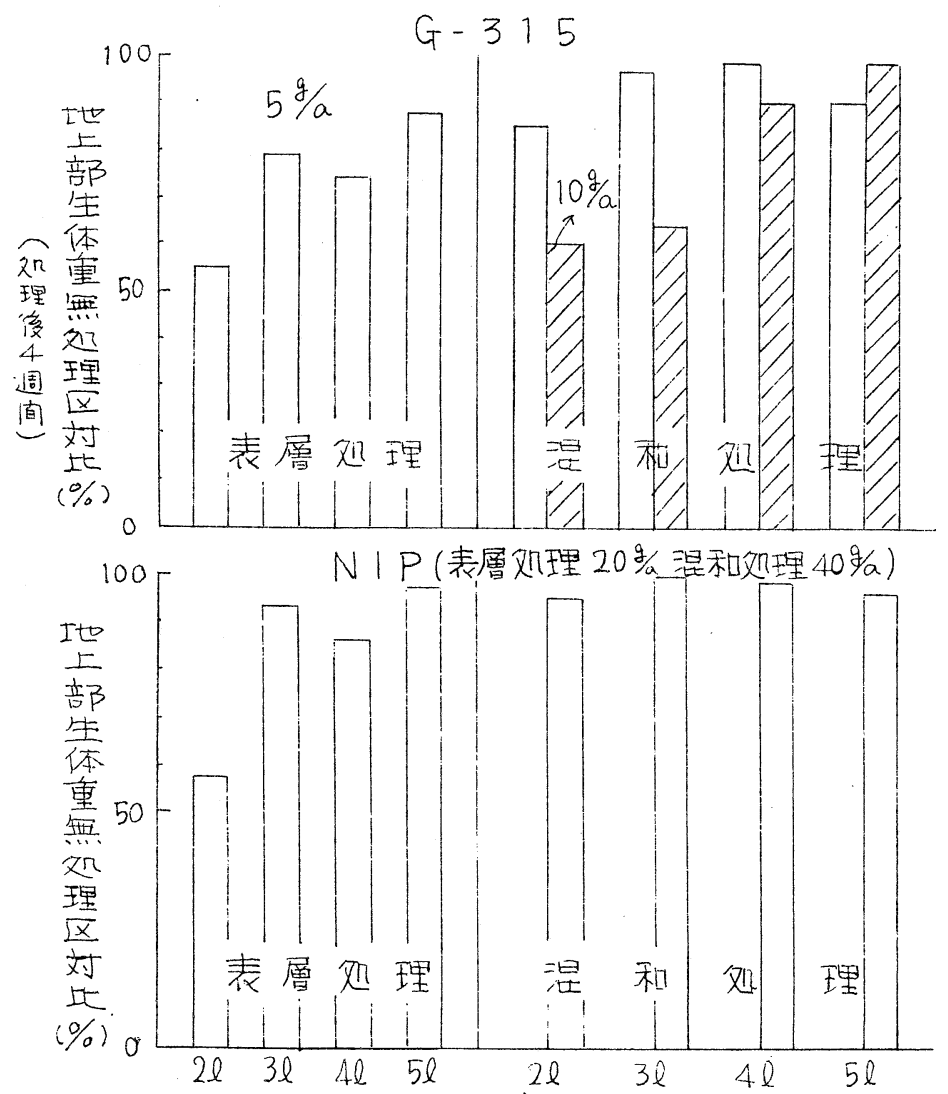

为1四水稻の亲令と苩害の関係。

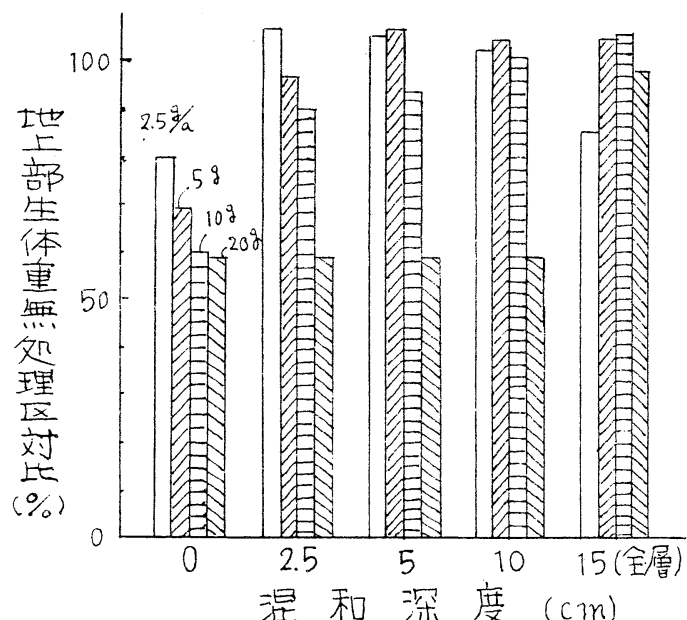

为2四混和深度と菒害の関係

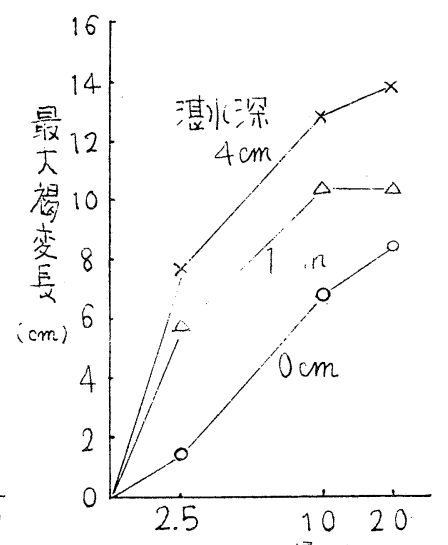

处理量 $g / a$

为了四: 观理䈉の湛水深と薬害の関侯 

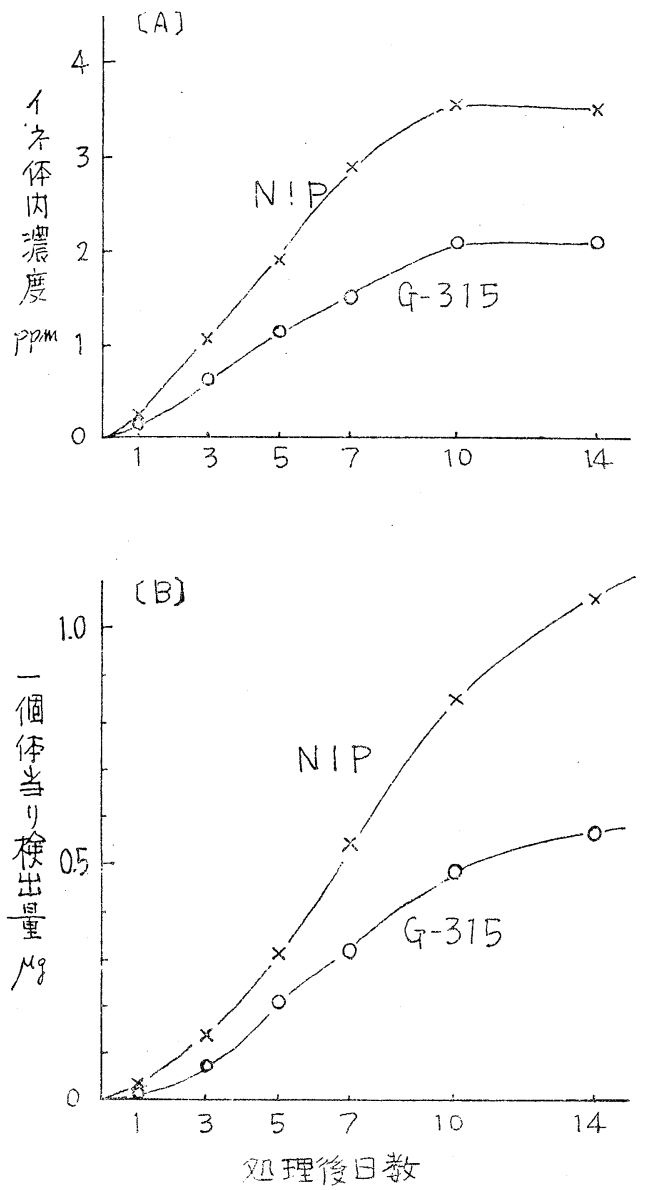

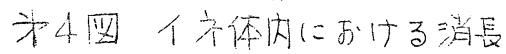

为、表个齐体内におけるG-3750分柿 ( ) 种井法)

\begin{tabular}{|c|c|c|c|c|c|}
\hline 部位 & 生低重 & 検出量 & 比率 & 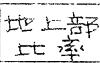 & 落度 \\
\hline$A$ & $12.63^{g}$ & $69.187^{\circ}$ & $42.1^{\%}$ & $67.1^{\%}$ & 5.478 \\
\hline B & $20 ?$ & $91.65 ?$ & 13.4 & 21.0 & 8.079 \\
\hline C & 2.79 & 0.242 & 3.2 & 5.1 & 1.879 \\
\hline D & 2.47 & 6.986 & 4.1 & 6.8 & 2827 \\
\hline$E$ & 8.14 & 61.218 & 37.3 & - & 7.521 \\
\hline 計 ${ }^{1)}$ & 20.57 & 103.068 & 627 & 100 & 5.011 \\
\hline 2) & 28.71 & 164.285 & 100 & - & 5.722 \\
\hline
\end{tabular}

1) IL上吾院 Total

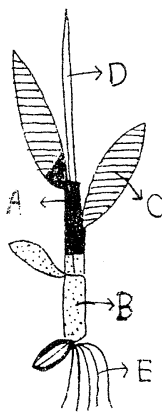

I)全体
イネ体内における分布の状態について 概要をつかもうとした。

尚コルベンはアルミはくでつつんで 根部に光の当たるのを防いだ。(下四 参照)

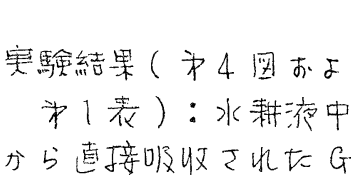
315 おでN|Pは濃度 的には枢め?颣似した 消長をたどつた。処理 聁10日程度は激增し。 以後平衝状熊を亦した。 処理濃度の经“G=315

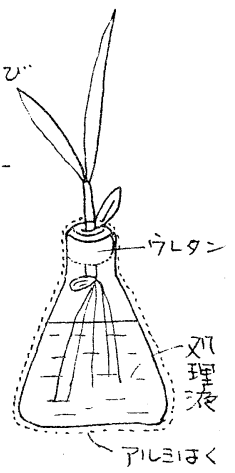
においても个齐呠助分

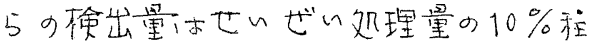
度であるので、この湄度の变代お、水 耕液中の濃腐变纰にの2起因レている とは考之られない。濃度的には平衡代 態となっても。量的には、14日後にす

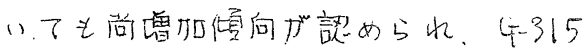
やNIPの場合には、少なくもも、DC

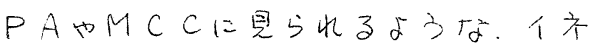
体内における分解解毒械能に存在し的 いと考之られる。一方个神体内におい てな、地上部では、裸变部分を令む菜

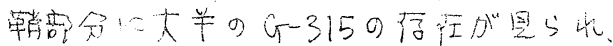
滦变の辇生している同し莱の菜 身也、观理淩展南上飞新菜中心 は余り分布していないとい亡偏 在性分認め心れ反。

\section{V: 䄍变症状の組織学的换討} 若干の知見を得区のでスライ ドにフ説明する。 


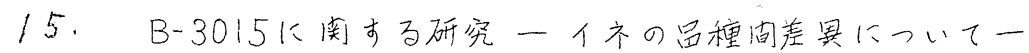

重松昭二, 本島建治, 木村一郎( 引ミア人化学工棠生物研究所)

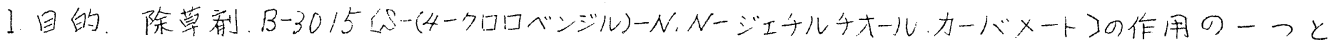

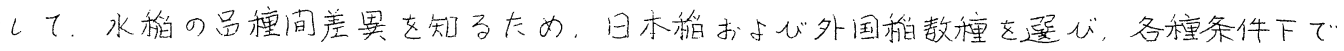
の初期生育におよぼす影響を橹討したので, 兰の結果を報告する。

2.栰料およ心゙方法。

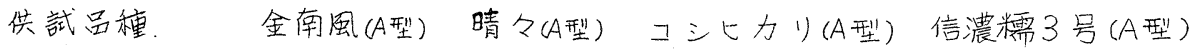

I.R-8 (C型) Tainan-3 (A型) Calrose (C型) Rafacllo ( $B$ 型)

供試葲剂。B-3015 50\%乳剂。

試験工。シャ一し内発宾試験。

经 $9 \mathrm{~cm}$ シャ一しを用い, 供試濃度菜夜 $20 \mathrm{ml}$ 中下扸胸档を播朣し、温空内下並べた。 調查は播祽後12日目下地上部長を測り, 抑制率を草出した。

試験吕。薬液浸清時间別, 発菜試験。

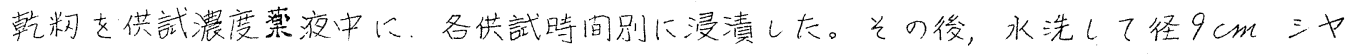

一レに播㮔し, 発宾試験女行口长。調查け, 播種後10 日目に地上部長を測定し, $20 \%$ 以上の地上部伸長抑制率を見た。

試験而。ステ一ジ別、ポット試験。

水田土壤女充填した径 $12 \mathrm{~cm}$ 白磁ポットに, 各下テージの水稳女準備し, 湛水(水深 $1 \mathrm{~cm}$ ) 土壤処理を行つた。調查は, 処理後20日目に地上部风乾重を测定し, 各ステ一ジでの 抑制率女草出した。

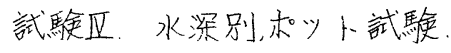

径 $12 \mathrm{~cm}$ 白磁和ットに水田土壤を充塻し, 乾田状態および 0 , 5 , $10 \mathrm{~cm}$ の水深女設定した。

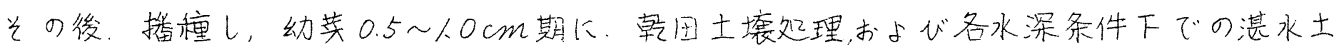
壤处理を行い, 各水深を保持した。調查け, 地上部门乾重を测り, 都制率を算出した。

3.結果およU゙考察.

試験工

各昌種のB-3015 下対する感受性を見ると。为1国のジとくで３０ｐｐｍ以上での差異

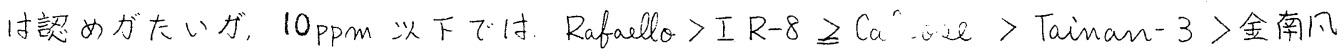
ニコシヒカリニ晴マニ信濃糯了号の順であった。 


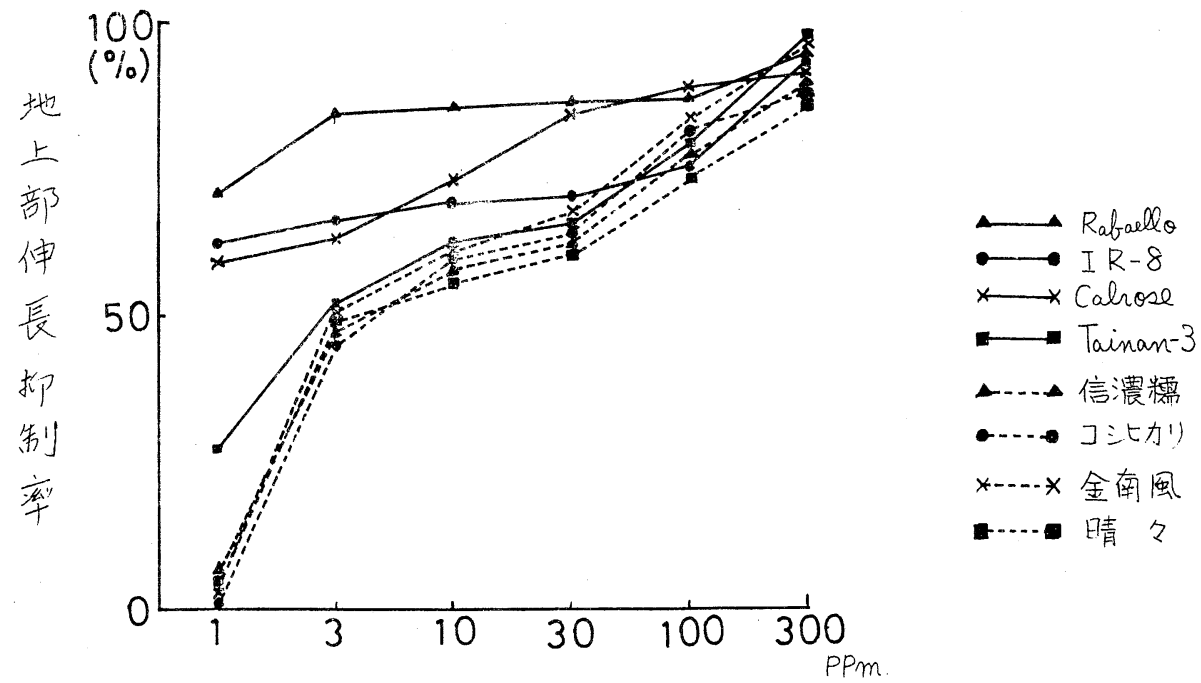

試䮓 I

次工国，供試濃度中での地上部伸長抑制

菜液中心浸清時间别抑制程度讨。

I R-8> Rafaello $=$ Calrose $>$

Tainan - 3>金南凡=晴々 二信

澴糯了号ミコミヒ力门の順であ

リ，試駼工の場合と浔将同じ傾

向を示にた。(単工表)

試験而

本实験においては，感受性に対し 昌種间差異与り, 迈理人テ一ジの 影響の方がはる力に大き力つた。

まず，処理下テ一ジと感受性の南 你艺是ると各昌種と王幼烡期>鳵 昒期>乾粉期>0.5葉期>1.0葉期て 西つ长。乾籾〜鳩胸期处理では。 合员㮔とも生育抑制ガ強く，特に 幼荠期处理でけ回復不能の害をう けた。一方, 0.5 葉期以降の処理で は, 各㽞種とも出葉の抑制程度で あつた。

次に, 㽞㮔间差異を見ると各处 理时期とも実験正の埸合と同じ順
妅表，20\%以上の抑制を示した浸漬時间

\begin{tabular}{|c|c|c|c|c|c|c|c|}
\hline & 1 & 3 & 10 & 30 & 100 & 300 & $1000^{\mathrm{FP} m}$ \\
\hline$I R-8$ & 48 & 48 & 24 & 6 & 6 & 6 & 6 \\
\hline Rafaello & 48 & 48 & 48 & 48 & 24 & 6 & 6 \\
\hline Taina:n3 & 48 & 48. & 48 & 48 & 48 & 6 & 6 \\
\hline Calrose & 48 & 48 & 48 & 48 & 24 & 6 & 6 \\
\hline 信濃糯 & 48 & 48 & 48 & 48 & 48 & 24 & 6 \\
\hline コシヒかり & 48 & 48 & 48 & 48 & 48 & 48 & 6 \\
\hline 晴 २ & 48 & 48 & 48 & 48 & 48 & 24 & 6 \\
\hline 金南风 & 48 & 48 & 48 & 48 & 48 & 24 & 6 \\
\hline
\end{tabular}

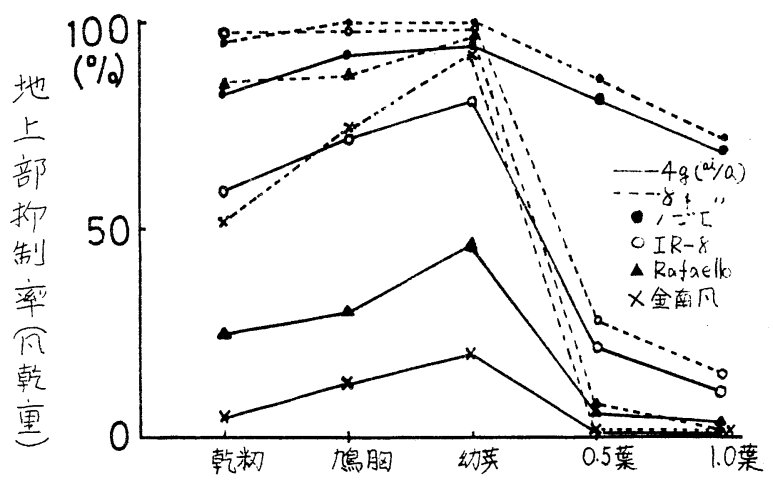

为亚图処理人テージと抑制の南係 
であつた。代表的なIR-8，Rafaelloおよய゙金南凡の場合を示すと，为正图の如くで ある。

試験区

各㽞種の水深別のB-3015 による抑制順位は。各水深とも試駛亚と同じであった。

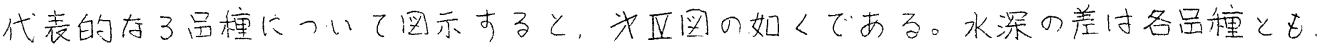
O cm> $5 \mathrm{~cm}>10 \mathrm{~cm}>$ 乾国状態, の傎向ガみられ，参考に播いた，ビ工ガ, 水深に比例 才るのと対照的友結果去示した。

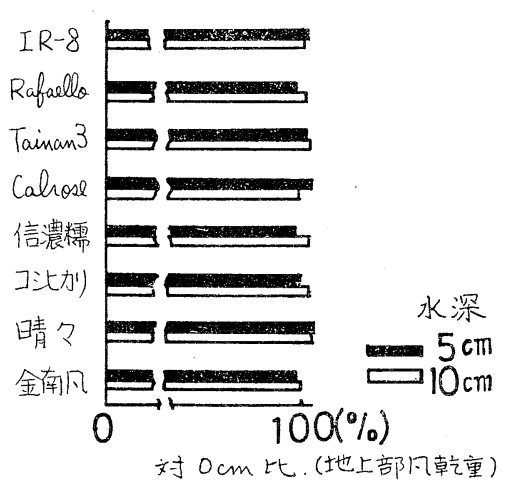

为正图。無処理区にお忛子、各水深 条件下での生育。

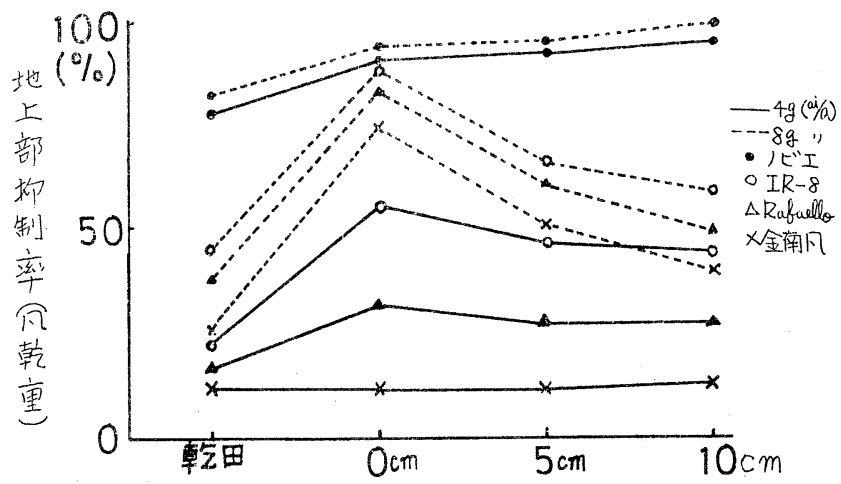

为立図各水深条件下での抑制。

\section{4.結論}

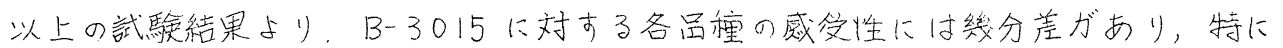
栽培型A，B，Cの了型间で差異が認められるのは，興味深い。この差が何に基因す るかけ，更に柣討する予定である。

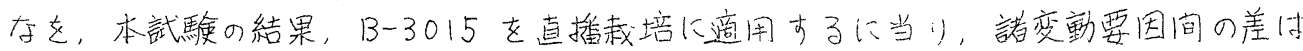

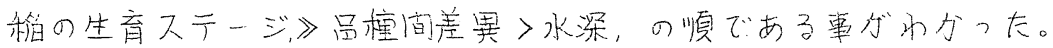

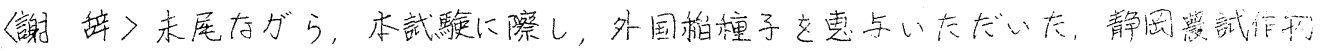
部の各位に対し，深く感謝の意を表す。 